\title{
Effect of the sodium hypochlorite and citric acid association on smear layer removal of primary molars
}

\section{Efeito da associação de hipoclorito de sódio e ácido cítrico na remoção de "smear layer" de molares decíduos}

\author{
Gabriela da Rosa Götze* \\ Cristiane Beatriz Costa Sales Cunha* \\ Laura Salignac de Souza Guimarães Primo** \\ Lucianne Cople Maia**
}

\begin{abstract}
This study aimed to assess the capacity of a sodium hypochlorite and citric acid (CA) association (the latter at different concentrations) in removing coronal smear layer (SL) of primary teeth. For this purpose, the pulp chamber roof and floor of 28 primary molars were removed to obtain enamel and dentine disks. SL was produced on the internal walls of the disks using high-speed drills. The disks were irrigated with $1 \%$ sodium hypochlorite and citric acid at different concentrations (CA-4\%, CA-6\%, CA-8\% and CA-10\%), and with $0.9 \%$ sodium chloride. The samples were split and observed under SEM. Scores were attributed to the obtained photomicrographs, according to the amount of SL present. It was noted that all the tested concentrations of citric acid used after the sodium hypochlorite were capable of removing SL. The results were analyzed by the Kruskal-Wallis test, and there was no significant statistical difference among the scores of the groups tested. However, it was observed that CA$8 \%$ and CA-10\% caused peritubular dentine destruction, and that CA-4\% presented a larger number of samples with dense SL. Based on these results, $6.0 \%$ citric acid in association with $1 \%$ sodium hypochlorite is suggested as auxiliary chemical substances for primary teeth irrigation.
\end{abstract}

DESCRIPTORS: Tooth, deciduous; Citric acid; Sodium hypochlorite; Endodontics; Smear layer.

\begin{abstract}
RESUMO: O objetivo deste estudo foi avaliar a capacidade da associação entre hipoclorito de sódio e ácido cítrico em diferentes concentrações para remover "smear layer" (SL) coronária de dentes decíduos. Para isso, foram utilizados 28 molares decíduos, nos quais se realizou a remoção do teto e do assoalho da câmara pulpar, obtendo-se discos de esmalte e dentina. Produziu-se SL nas paredes internas dos discos utilizando-se brocas em alta rotação e eles foram irrigados com hipoclorito de sódio a 1\%, ácido cítrico em diferentes concentrações (AC- 4\%, AC- 6\%, $\mathrm{AC}-8 \%$ e $\mathrm{AC}-10 \%)$ e cloreto de sódio a $0,9 \%$. As amostras foram esplitadas e observadas no MEV. Foram atribuídos escores às fotomicrografias obtidas, de acordo com a quantidade de SL presente. Observou-se que todas as concentrações de ácido cítrico empregadas após o hipoclorito de sódio foram capazes de remover SL. Os resultados foram analisados pelo teste de Kruskal-Wallis, não havendo diferença estatística significativa entre os escores dos grupos testados. Verificou-se, entretanto, que AC- $8 \%$ AC-10\% promoveram destruição de dentina peritubular e que $\mathrm{AC}-4 \%$ apresentou maior número de amostras com SL densa. A partir dos resultados obtidos sugere-se a utilização de ácido cítrico a $6,0 \%$ em associação ao hipoclorito de sódio a 1\% como substâncias químicas auxiliares para irrigação de dentes decíduos.
\end{abstract}

DESCRITORES: Dente decíduo; Ácido cítrico; Hipoclorito de sódio; Endodontia; Camada de esfregaço.

\section{INTRODUCTION}

The smear layer (SL) is an amorphous layer formed by organic and inorganic components generated by cavity and endodontic preparations ${ }^{12}$.

In spite of the negative influence of this layer on the success of endodontic treatment its removal is still controversial ${ }^{3,5,8,11}$. Some authors believe that the maintenance of this layer is beneficial ${ }^{18,20}$. A large number of studies, however, recommend its removal, promoting increased dentine perme- ability, which contributes to better disinfection and sealing of root canals ${ }^{6,7,13,18,21}$.

Various irrigating solutions at different concentrations and irrigation times have been tested with the purpose of improving the removal of SL in permanent teeth, the combinations between chelating agents and sodium hypochlorite being outstanding $8,19,21,22,23$. Among these associations,

*Graduate Students; **Professors - Department of Pediatric Dentistry and Orthodontics, Federal University of Rio de Janeiro. 
Götze GR, Cunha CBCS, Primo LSSG, Maia LC. Effect of the sodium hypochlorite and citric acid association on smear layer removal of primary molars. Braz Oral Res 2005;19(4):261-6.

sodium hypochlorite and citric acid composites have shown proven efficiency in the reviewed literature ${ }^{3,4,17,19}$.

Nevertheless, studies with reference to the use of these irrigating solutions, capable of removing SL in primary teeth, are scarce. Although Salama, Abdelmegid $^{17}$ (1994) and Pitoni et al. ${ }^{14}$ (2001) obtained good results in in vitro studies carried out with primary teeth, using $5.0 \%$ citric acid, as well as Primo et al. ${ }^{15}$ (2002), using $10 \%$ citric acid, there is no consensus with regard to the ideal concentrations for the use of these substances in Pediatric Dentistry practice.

This study aimed to assess the capacity of sodium hypochlorite in association with citric acid at different concentrations as auxiliary chemical substances in removing the coronary SL of primary teeth.

\section{MATERIALS AND METHODS Sample selection}

Twenty-eight primary molars from the Human Teeth Bank, department of Pediatric Dentistry, School of Dentistry, Federal University of Rio de Janeiro (UFRJ), with healthy crowns, previously stored in saline solution under refrigeration, were selected.

This study was submitted to the local Ethical Committee for appreciation and was approved (protocol 097/04).

\section{Sample preparation}

Initially, the root remainders of the teeth were removed with a single faceted diamond disk (Microdent, São Paulo, SP, Brazil) at low speed. Afterwards, access to the pulp chamber was obtained with the use of a diamond tip No. 1012 (KG Sorensen, São Paulo, SP, Brazil), at high speed and under water cooling, so that all of its roof and floor were removed. Thus, enamel and dentine disks were obtained (Figure 1). The drills used were replaced after every 5 preparations.

In addition to the SL generated during access to the pulp chamber, an additional amount was produced on the internal walls of the tooth disks by means of circular movements with a carbide drill No. 4 (KG Sorensen), at high speed and under cooling.

The teeth were randomly distributed into 4 groups, according to the auxiliary substances used to irrigate them. The teeth were held in place with a pair of dental tweezers, in a plastic bowl, where they were irrigated. For this irrigation $10 \mathrm{ml}$ disposable syringes (23-gauge needle) were used. Initially, all groups received irrigation with $5 \mathrm{ml}$ of $1 \%$ sodium hypochlorite (NaOCl) (Fórmula e Ação, São Paulo, Brazil) for 15 seconds. After that, each group received irrigation with $10 \mathrm{ml}$ of citric acid (Fórmula e Ação, São Paulo, Brazil) for 30 seconds at the following concentrations: $4.0 \%(\mathrm{CA}-4), 6.0 \%$ (CA-6), 8.0\% (CA-8) and 10.0\% (CA-10). Then, final irrigation was done with $10 \mathrm{ml}$ of $0.9 \%$ saline solution (Laboratório Sanobiol, Pouso Alegre, Brazil) for 30 seconds. All internal surfaces of the dental disks were tapped with irrigation. Each irrigation was simultaneously aspired with an endodontic aspirator (25-gauge; $186 \mathrm{ml} /$ minute suction capacity).

Next, longitudinal grooves, which did not penetrate into the pulp chamber, were made on the mesial and distal surfaces of samples, using a single faceted diamond disk (Microdent), to facilitate their fracture. The disks were then split at these grooves to obtain 56 hemi-disks (Figure 1),

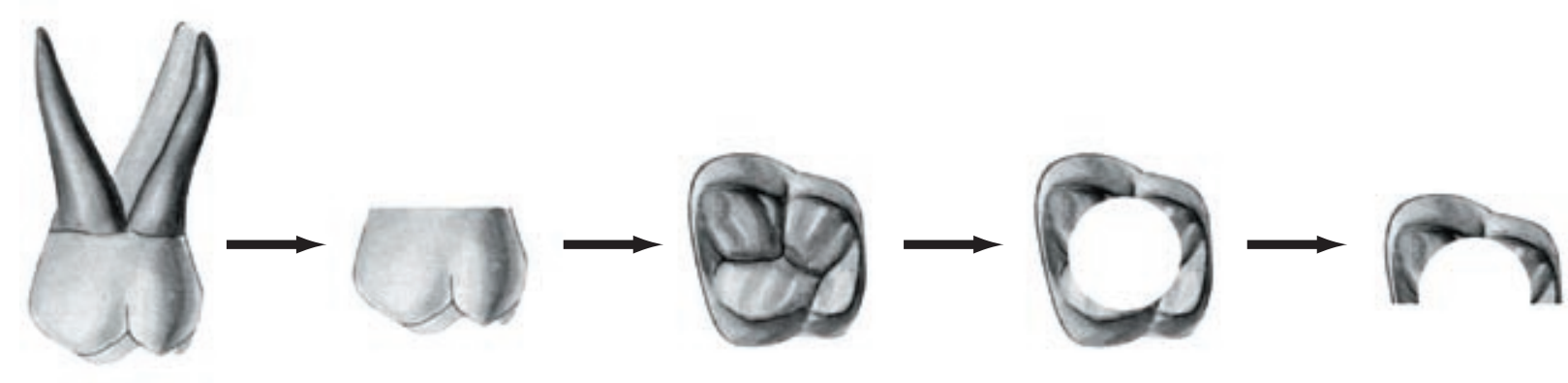

FIGURE 1 - Illustrative diagram of the stages of sample preparation for assessment by Scanning Electron Microscope. 
Götze GR, Cunha CBCS, Primo LSSG, Maia LC. Effect of the sodium hypochlorite and citric acid association on smear layer removal of primary molars. Braz Oral Res 2005;19(4):261-6.

by means of a slight stroke of a small hammer. This method was chosen to prevent or minimize the formation of the smear layer that results from the separation of the samples. These were then prepared for observation under a Scanning Electron Microscope (JEOL - 5310, Tokyo, Japan).

Photomicrographs $(2,000 \mathrm{X})$ were obtained from the most concave region of each hemi-disk. The samples were assessed blindly by three previously calibrated examiners (weighted Kappa $=0.864$ ), who attributed scores to the images obtained according to the criteria proposed by Antonio et al. ${ }^{1}$ (2003) (Chart 1). The data were entered in the GMC 2002 computer program (Georgia, USA) and statistically analyzed by the Kruskal-Wallis non-parametric test at a $5 \%$ level of significance.

\section{RESULTS}

The results found after analyzing the photomicrographs demonstrated that there was no significant statistical difference among the groups $(p=0.158)$ (Table 1). It was, however, noted that the SL removal pattern varied according to the concentration of citric acid used.

CHART 1 - Scores attributed to the photomicrographs according to the criteria of Antonio et al. ${ }^{1}$ (2003).

\begin{tabular}{l}
\hline \hline Scanning Electron Microscope Assessment Criteria \\
\hline 0 - Absence of smear layer \\
\hline 1 - Moderate smear layer \\
\hline 2 - Dense smear layer, with visible tubules \\
\hline - Dense smear layer, without visible tubules \\
\hline \hline
\end{tabular}

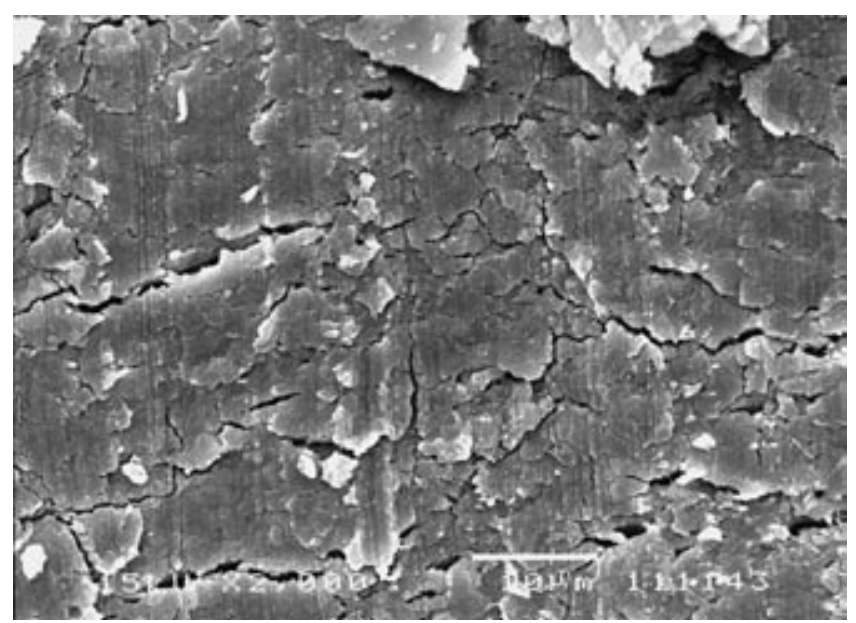

FIGURE 2 - Representative photomicrograph of the score 3 attributed to the groups $(2,000 \mathrm{X})$.
In $\mathrm{CA}-4 \%$ the absence of SL (score 0) was found in $50.0 \%$ of the samples, but $21.43 \%$ of them presented score 3 (Figure 2), i.e., the worst SL removal pattern.

While in CA-6\% no predominance of any score was seen, scores 0 (Figure 3) and 1 (Figure 4) occurred with the same frequency (42.9\%). In CA-8\% there was a greater occurrence of score 1 (57.14\%); score 3 (Figure 2) was not observed in any sample. It was also observed that CA-10\% had a greater percentage of scores $0(57.14 \%)$, and that score 2 (Figure 5) was not observed.

Although observation of the diameters of the dentinal tubules was not the aim of this paper, this was inevitable because they broadened, indicating the presence of damage to the peritubular dentin. This was observed in those groups where greater concentration of citric acid was used (CA$8 \%$ and CA-10\%), particularly in CA-10\% (Figure 6). The peritubular dentine in $50 \%$ of the samples in CA-10\% presented some degree of destruction, whereas the same occurred to $35.5 \%$ of the samples in CA-8\%.

TABLE 1 - Percentages of score distribution with regard to smear layer removal in each group $(\mathrm{p}=0.158)$.

\begin{tabular}{c|r|r|r|c}
\hline \hline Score & $\begin{array}{c}\text { CA-4.0\% } \\
(\mathrm{n}=14)\end{array}$ & $\begin{array}{c}\text { CA-6.0\% } \\
(\mathrm{n}=14)\end{array}$ & $\begin{array}{c}\text { CA-8.0\% } \\
(\mathrm{n}=14)\end{array}$ & $\begin{array}{c}\text { CA-10.0\% } \\
(\mathrm{n}=14)\end{array}$ \\
\hline 0 & $50.00 \%$ & $42.86 \%$ & $28.57 \%$ & $57.14 \%$ \\
\hline 1 & $21.43 \%$ & $42.86 \%$ & $57.14 \%$ & $35.71 \%$ \\
\hline 2 & $7.14 \%$ & $7.14 \%$ & $14.29 \%$ & 0 \\
\hline 3 & $21.43 \%$ & $7.14 \%$ & 0 & $7.15 \%$ \\
\hline \hline
\end{tabular}

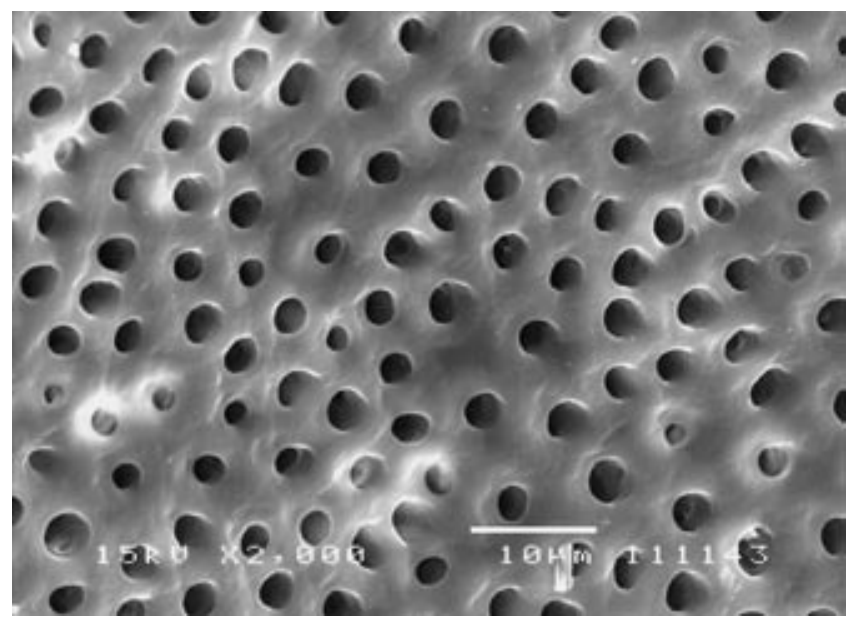

FIGURE 3 - Representative photomicrograph of the score 0 attributed to the groups $(2,000 \mathrm{X})$. 
Götze GR, Cunha CBCS, Primo LSSG, Maia LC. Effect of the sodium hypochlorite and citric acid association on smear layer removal of primary molars. Braz Oral Res 2005;19(4):261-6.

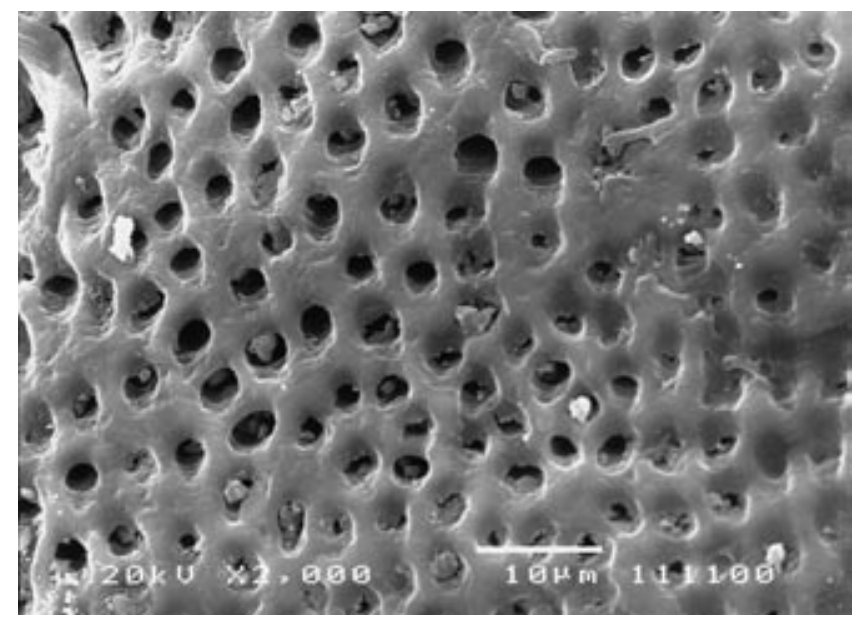

FIGURE 4 - Representative photomicrograph of the score 1 attributed to the groups $(2,000 \mathrm{X})$.

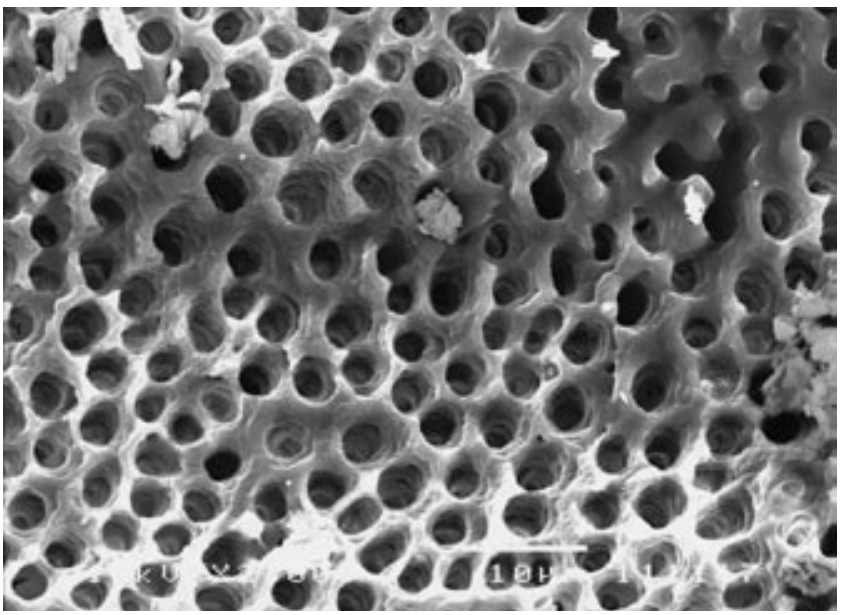

FIGURE 6 - Representative photomicrograph of the observed dentinal tubule enlargement, suggesting peritubular dentine damage $(2,000 \mathrm{X})$.

Nonetheless, this characteristic was not seen in the other two groups, in which lower acid concentrations were used.

\section{DISCUSSION}

The option to do this study with primary teeth had the objective of testing SL removal, because although various auxiliary chemical substances have already been recognized as efficient for permanent teeth in the reviewed literature, their effects on primary dentition are not widely known. However, because of the difficulty of obtaining primary teeth with roots, due to the rhyzolysis process, this study assessed SL removal at the coronal portions of these teeth.

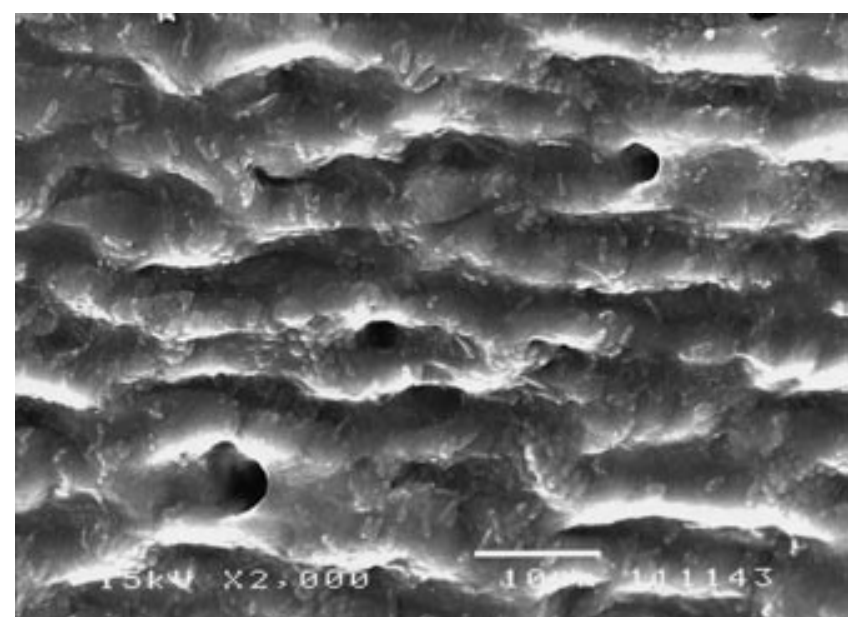

FIGURE 5 - Representative photomicrograph of the score 2 attributed to the groups $(2,000 \mathrm{X})$.

Drills were used instead of endodontic files to produce SL in the samples in this study due to the easiness of this procedure and the clinical similarity of the results obtained with both types of instruments ${ }^{4}$.

The choice of associating sodium hypochlorite to citric acid came from the good results found in permanent teeth, as it is routinely used in their endodontic therapy ${ }^{3,4,17,19}$. The efficacy of these auxiliary chemical substances is explained by the fact that they allow better penetration and adaptation of the filling material to the root canals. Furthermore, their use provides better disinfection of root canals, as the two substances used together constitute a more efficient irrigation than each of them used separately ${ }^{19,21}$. Such effects occur because while citric acid opens dentine tubules, thus aiding the penetration of the filling material $^{4,6,13,17,22}$, sodium hypochlorite has a bactericidal action, removing organic matter ${ }^{2,9}$.

With regard to the saline solution, it plays the role of a final irrigating agent, with the objective of removing crystals resulting from the reaction of the citric acid with dentine, which interfere with the identification of SL removal under SEM ${ }^{17}$.

The results of this study showed that all the concentrations used were capable of removing SL, without statistical difference among the groups. This finding corroborates studies described in the reviewed literature, in which citric acid was shown to be efficient at concentrations ranging from $6.0 \%$ to $50.0 \%$

However, in spite of all the concentrations of citric acid being capable of removing SL without statistical differences, changes were noted in the 
Götze GR, Cunha CBCS, Primo LSSG, Maia LC. Effect of the sodium hypochlorite and citric acid association on smear layer removal of primary molars. Braz Oral Res 2005;19(4):261-6.

dentine walls of some elements when higher concentrations were used. These effects could be observed in CA-8\% and CA-10\%, in which part of the samples presented peritubular dentine destruction, not found in the other studied groups. These findings corroborate those related by Haznedarog$1 u^{10}$ (2003), who also found peritubular dentine destruction after irrigating dog teeth with citric acid at concentrations of $10.0 \%, 25.0 \%$ and $50.0 \%$.

Concentrations of $8.0 \%$ and $10.0 \%$ do not seem to be the most adequate for use in primary teeth, whose root canal dentinary thickness is diminished, which makes it damage-prone ${ }^{16,17}$. This can be added to the fact that the potential effects of the damage to the dentinary structure are not totally known ${ }^{10}$.

Therefore, based on the results of this study, in which lower concentrations of citric acid were capable of removing SL without causing damage to the dentinary structure, such concentrations are more indicated for primary teeth.

Although the results with regard to SL removal in CA-4\% were not statistically different from those of the other groups, it was observed that the greatest frequency of score $3(21.43 \%)$ occurred in this group, i.e., the presence of dense SL, without vis-

\section{REFERENCES}

1. Antonio AG, Moraes RS, Cunha CBCS, Primo LSSG, Maia LC. Eficácia do Carisolv e de substâncias químicas auxiliares na remoção da "smear layer" radicular bovina. In: 20ª Reunião Anual da SBPqO: 2003; Águas de Lindóia. Anais. São Paulo: Sociedade Brasileira de Pesquisa Odontológica; 2003. p. 168.

2. Baumgartner JC, Cuenin PR. Efficacy of several concentrations of sodium hypochlorite for root canal irrigation. $\mathrm{J}$ Endod 1992;18:605-12.

3. Baumgartner JC, Mader CL. A scanning electron microscopic evaluation of four root canal irrigation regimens. $J$ Endod 1987;13:147-57.

4. Calas P, Rochd T, Michel G. In vitro attachment of Streptococcus sanguis to the dentine of the root canal. J Endod 1994;20:71-4.

5. Czonstkowsky M, Wilson EG, Holstein FA. The smear layer in endodontics. Dent Clin North Am 1990;34:13-25.

6. Garberoglio R, Becce C. Smear Layer removal by root canal irrigants. A comparative scanning electron microscopic study. Oral Surg Oral Med Oral Pathol 1994;78:359-67.

7. Goldberg F, Abramovich A. Analysis of the effect of EDTAC on the dentinal walls of the root canal. J Endod 1977;3:1015.

8. Goldman M, Goldman LB, Cavaleri R, Bogis J, Lin PS. The efficacy of several endodontic irrigating solutions: a scanning electron microscopic study: part 2. J Endod 1982;8:487-92. ible dentine tubules. Therefore, it is suggested that among the lower concentrations tested, citric acid at $6.0 \%$ may be considered as an option for SL removal in primary teeth, since it demonstrated better results than CA-4\% in this study, as it presented a lower frequency of score 3 (dense SL).

It is worth emphasizing, however, that further clinical studies to assess the behavior of primary teeth submitted to endodontic therapy using the suggested auxiliary chemical solutions are of fundamental importance.

\section{CONCLUSION}

All different concentrations of citric acid associated to sodium hypochlorite tested in the present study proved effective in removing coronary SL from deciduous molars. It was observed, however, that CA- $8 \%$ and CA-10\% caused the broadening of dentinal tubules, suggesting damage to the peritubular dentine, and that CA-4\% presented a larger number of samples with thick SL. Therefore, the use of $6.0 \%$ citric acid in association with $1.0 \%$ sodium hypochlorite is suggested as auxiliary chemical substances for irrigating primary teeth.

9. Gutiérrez JH, Jofré A, Villena F. Scanning electron microscope study on the action of endodontic irrigants on bacteria invading the dentinal tubules. Oral Surg Oral Med Oral Pathol 1990;64:491-501.

10. Haznedaroglu F. Efficacy of various concentrations of citric acid at different $\mathrm{pH}$ values for smear layer removal. Oral Surg Oral Med Oral Pathol Oral Radiol Endod 2003;96:340-4.

11. Liolios E, Economides N, Parissis-Messimeris S, Boutsioukis A. The effectiveness of three irrigating solutions on root canal cleaning after hand and mechanical preparation. Int Endod J 1997;30:51-7.

12. McComb D, Smith D. A preliminary scanning electron microscopic study of root canals after endodontic procedures. J Endod 1975;1:238-42.

13. Pashley DH, Michelich V, Kehl T. Dentin permeability: effects of smear layer removal. J Prosthet Dent 1981;46:531-7.

14. Pitoni CM, Figueiredo MC, Souza MAL. Micromorfologia da dentina de dentes decíduos submetidos a instrumentação endodôntica. In: XVIII Reunião Anual da SBPqO: 2001; Águas de Lindóia. Anais. São Paulo: Sociedade Brasileira de Pesquisa Odontológica; 2001. p. 152.

15. Primo LG, Chevitarese O, Guedes-Pinto AC. Efficacy of irrigating solutions in removing radicular smear layer from anterior primary teeth. J Dent Res 2002;81:411. 
Götze GR, Cunha CBCS, Primo LSSG, Maia LC. Effect of the sodium hypochlorite and citric acid association on smear layer removal of primary molars. Braz Oral Res 2005;19(4):261-6.

16. Ruschel HC, Chevitarese O. A comparative study of dentin thickness of primary human molars. J Clin Pediatr Dent 2003;27:277-81.

17. Salama FS, Abdelmegid FY. Six percent citric acid better than hydrogen peroxide in removing smear layer: an in vitro pilot study. Pediatr Dent 1994;16:424-6.

18. Saunders WP, Saunders EM. Influence of smear layer on the coronal leakage of Thermafil and laterally condensed gutta-percha root fillings with glass ionomer sealer. J Endod 1994;20:155-8.

19. Scelza MFZ, Antoniazzi JH, Scelza P. Efficacy of final irrigation - a scanning electron microscopy evaluation. J Endod 2000;26:355-8.
20. Sen BH, Wesselink PR, Türkün M. The smear layer: a phenomenon in root canal therapy. Int Endod $\mathrm{J}$ 1995;28:141-8.

21. Smith JJ, Wayman BE. An evaluation of the antimicrobial effectiveness of citric acid as a root canal irrigant. J Endod 1986;12:54-8.

22. Wayman B, Kopp WM, Pinero J, Lazzari EP Citric and lactic acids as root canal irrigants in vitro. J Endod 1979;5:258-65.

23. Yamada RS, Armas A, Goldman M, Lin PS. A scanning electron microscopic comparison of a high volume final flush with several irrigating solutions: part 3. J Endod 1983;9:137-42.

Received for publication on Oct 20, 2004

Sent for alterations on Apr 27, 2005

Accepted for publication on Sep 29, 2005 